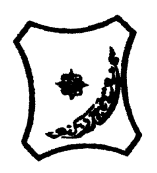

Bayero Journal of Pure and Applied Sciences, 12(1): 151 - 154

Received: February, 2019

Accepted: June, 2019

ISSN $2006-6996$

\title{
A SURVEY OF TICK INFESTATION ON CATTLE IN SELECTED AREAS OF BAUCHI NORTH SENATORIAL ZONE, BAUCHI STATE, NIGERIA
}

\begin{abstract}
Usman A.M ${ }^{1}$ and Malann, Y. ${ }^{2}$
1. Biological Science Department, Nigerian Army University Biu, Borno State, Nigeria.

2. Department of Biological Sciences, University of Abuja, FCT

Corresponding Author: Biological Science Department, Nigerian Army University Biu, PMB 1500 Biu, Borno State, Nigeria; +2348035175659

MAIL:usman.alhajimohammed55@gmail.com, malannyd@gmail.com, +2347068259209

ABSTRACT

Tick-borne diseases are spread throughout the world but are most numerous and exerting greatest impact in the tropical and subtropical regions. The survey of tick infestation on cattle was carried out in Bauchi North Senatorial Zone,Bauchi State, Nigeria to ascertain the impact of ticks on their host.Ticks specimens were collected by detaching them from their host using a forceps. The results showed that 1719 ticks were recovered from the randomly selected200 cattle examined. The species found were 900(53\%) Amblyommaspecies,637(37\%) Boophilusspecies, 159(9\%) Hyalommaspecies and 23 (1\%) Rhipicephalus species. The infestation of ticks was higherin Giade 554(32\%) followed by Itasgadau 523(30\%), Jama'are336(20\%) and Katagum $306(18 \%)$. It was also higher in Female cattle 982(57\%) than the male 737(43\%) cattle and in White Fulani followed by SokotoGudali and Red Bororo with 1193(69\%), $386(23 \%)$ and $140(8 \%)$ respectively. from the result of this study tick infestation was high and this has serious economic implication as it reduce the productivity of the farmers and also has the potential infliction causes of diseases to both cattle and human. Therefore, appropriate control measures should be instituted by the authorities to minimize these losses in production as well as educating the farmers on the effect of tick infestation on their cattleand cattle consumers in study area.

Keywords: Tick, Cattle, Infestation, Bauchi
\end{abstract}

\section{INTRODUCTION}

Ectoparasites, particularly ticks, are important parasites because of their voracious bloodfeeding activity and as vectors for various agents of diseases in both man and livestock (Cumming, 1998). In Nigeria parasites constitute a major constrain to livestock production (Fabiyi, 1984). Certain factors have been observed to affect the distribution of ectoparasites to their host. Among some are the season (James-Rugu and Iwuala, 2002) and mode of livestock rearing or system (James-Rugu and Iwuala, 1995). Tickborne diseases were again ranked high in terms of their impact on the livelihood of resource poor farming communities in developing countries (Perry et al. 2002). This is particularly relevant in parts of sub-Saharan Africa, Asia and Latin America, were the demand for livestock products is increasing rapidly (Delgado, 1999). Eight hundred and ninety six (896) tick species were recognized worldwide (Guglielmone et al., 2010)
Ticks of domestic animals directly cause poor health and loss of production to their hosts by many parasitic mechanisms. Ticks also transmit numerous kinds of viruses, bacteria, and protozoa between domestic animals (Walter, 2017). Most of the investigations on prevalence of tick species in Africa (Nigeria) are more than a decade old (Perry, et al, 2002)whereas periodical monitoring of tick infestation is an essential component for formulating effective control measures. The impact of ticks and tick borne diseases on the individual and national economics warrants application of appropriate tick control strategies on priority basis (Basil, 2005). Therefore the present study was conducted to determine the tick infestation on cattle in the Bauchi North senatorial zone in relation to sex, breed, and location for proper control measures. 
BAJOPAS Volume 12 Number 1, June, 2019 MATERIAL AND METHODS

Study Area

The study was conducted in Bauchi North Senatorial Zone, Nigeria. Seven Local Governments make up the zone out of the twentyLocal Governments of the state which includes Katagum, shira, Jama'are, Itas/ Gadau, Zaki, Gamawa and Giade. The zone occupies a total land of $9717 \mathrm{~km}$ representing about $20.2 \%$ of the state's total land area. The vegetation of the zone is Sudan savannah ecosystem. The major climate elements that influence the climate of the study area and affecting the farming system are temperature and precipitation (rainfall), the annual temperature ranged between 22-330 C from April to May (Bashir et al.,2001). The mean annual rainfall ranged between $615.6-985 \mathrm{~mm}$ with peak between July- Augusts.

\section{Sample Collection}

Random sampling techniques were used to select 200 cattle from four selected Local Governments of this Senatorial zone and 50 cattle in each selected Local Government. Ticks specimens were collected by detaching them from their host using a forceps. All parts of the body of cattle were carefully examined. The ticks collected were stored in container containing $70 \%$ alcohol for later identification in the laboratory. The containers were label base on the location, breed and sex of the sample collected. The samples collected were then transported to the Laboratory for identification using method described by Wall and Shearer (1997).

\section{Statistical Analysis}

The result obtained were analyzed using chisquare for any significant differences on the incidence of tick infestation in different location, breeds and sex at $\mathrm{P}<0.05$ level of significance, simple percentage and frequency were used to present the results.

\section{RESULTS AND DISCUSSION}

Livestock industry in Nigeria is faced with many problems and one of such problems is parasitic diseases (Jawara, 1990). Parasitic infection is known to cause great econosmic losses in livestock production in Africa in general (Ajayi, 1995). In this study, four genera of ticks were encountered with Amblyomma species with the highest prevalence followed by Boophilus species, Hyalomma Species and Rhipicephalus species with 900(53\%), 637(37\%), 159(9\%) and $23(1 \%$ ) respectively (table 1 ). This species encountered were similarly encountered by many researchers such as(Fabiyi, 2007; Owolabiet al, 2015; Obadiah and Shekaro2012;Joseph, et al., 2014).The Rhipicephalus species which is the least prevalence species in this study, this is because is accidental ectoparasite (tick). Rhipicephalus species have been reported to have preference of dog as host (Ouhelli and Pandey, 1982). And this is possible because some of the cattlerearers are using dog which usually help them for security and hunting.

Table 1: Distribution and Abundance of Ticks Species Collected during the study

\begin{tabular}{lll}
\hline Species of ticks & No. collected & Percentage \\
\hline Amblyommavariegatum & 675 & 39 \\
Amblyommasplendidum & 225 & 13 \\
Boophilusannulatus & 324 & 19 \\
Boophilusdecolaratus & 222 & 13 \\
Boophilusgeigyi & 91 & 5 \\
Hyalommarufipes & 64 & 4 \\
Hyalommatrancatum & 95 & 6 \\
Rhipicephalusspecies & 23 & 1 \\
\hline Total & $\mathbf{1 7 1 9}$ & $\mathbf{1 0 0}$ \\
\hline Table 2: Sex Related Ticks Infestation on Cattle in Sample & Area \\
\hline Sex & Frequency & Percentage \\
\hline Male (Bull) & & \\
Amblyomma species & 411 & 56 \\
Boophilusspecies & 267 & 36 \\
Hyalomma species & 49 & 7 \\
Rhipicephalus species & 10 & 1 \\
Sub-total & $\mathbf{7 3 7}$ & $\mathbf{4 3}$ \\
\hline Female (Cow) & & \\
Amblyomma species & 489 & 50 \\
Boophilusspecies & 370 & 38 \\
Hyalomma species & 110 & 11 \\
Rhipicephalus species & 13 & 1 \\
Sub-total & $\mathbf{9 8 2}$ & $\mathbf{5 7}$ \\
\hline Total & $\mathbf{1 7 1 9}$ & $\mathbf{1 0 0}$ \\
\hline & & \\
\hline
\end{tabular}


Table 3: Ticks Infestation on Cattle in Sample Area Based on breed

\begin{tabular}{llll}
\hline Breed & No of Cattle Examined & Frequency & Percentage \\
\hline White Fulani & 145 & 1193 & 69 \\
SokotoGudali & 39 & 386 & 23 \\
Red Bororo & 16 & 140 & 8 \\
\hline Total & $\mathbf{2 0 0}$ & $\mathbf{1 7 1 9}$ & $\mathbf{1 0 0}$ \\
\hline $\mathrm{X}^{2}$ &
\end{tabular}

$\mathrm{X}^{2}$ calculated $=0.17 ; \mathrm{X}^{2}$ tabulated $=5.99, \mathrm{df}=2, \mathrm{P}>0.05$

Table 4: Ticks Infestation on Cattle in Sample Area Based on Location

\begin{tabular}{llll}
\hline Location & No of Cattle Examined & Frequency & Percentage \\
\hline Katagum & 50 & 306 & 18 \\
Itasgadau & 50 & 523 & 30 \\
Jama'are & 50 & 336 & 20 \\
Giade & 50 & 554 & 32 \\
\hline Total & $\mathbf{2 0 0}$ & $\mathbf{1 7 1 9}$ & $\mathbf{1 0 0}$
\end{tabular}

$\mathrm{X}^{2}$ calculated $=11.84 ; \mathrm{X}^{2}$ tabulated $=7.81, \mathrm{df}=3, \mathrm{P}>0.05$

The study showed that, the infestation of ectoparasite by the tick is higher in female $57 \%$ than male $43 \%$ cattle (Table 2 ). This study is in agreement with the earlier report of Malannet al. (2016) but contrary to the report of Obadiahet al. (2017) and Obadiah and Shekaro (2012) who reported high infestation in male than female which may be due to different method of rearing and the rearing environment, but it is worth to note that all species examined occurred in both sexes of the cattle. The infestation rate is higher in white Fulani breed than other breed. White Fulani breed is the most abundant breed in the study area. The Red Bororo and SokotoGudali breed were not much in the area as(table 3). Also, the infestation rate was not statistically different among the species ( $P>0.05)$. Obadiah and Shekaro (2012) reported that no breed were completely resistance to tick infestation.

The tick infestation based on location on the cattle was higher in Giade with 32\% followed by Itas-Gadau, Jamare and katagum with $30 \%$,

\section{REFERENCES}

Ajayi, S.T. (1995). An overview of livestock productivity in Nigeria. Paper presented at $A \quad$ National Workshop on Nutrition and Health as constraints to increased Livestock Productivity in Nigeria, Bauchi, 14th_16th November.

Bansal, G.C. (2005). Bovine theileriosis in India: An overview. Proceeding of National Academy of Sciences India, 75: 134-43.

Bashir, M.M., Bala, A., Mohammed, I.T., Isa, H.J., Adamu, M.B., Hamisu, M.S. and Abdullahi, A. (2001).Request for the creation of Katagum state out of the present Bauchi state of Nigeria. $A$ memorandum submitted to the speakers house of representatives, national assembly, Abuja, Nigerí. 1-28pp.
$20 \%$ and $18 \%$ respectively. The infestation rate in different location was statistically significant $(P<0.05)$. This may be due to the rearing method and dirty environment where the tick thrive are readily found and also it may attribute to more awareness in urban areas than rural.

\section{CONCLUSION AND RECOMMENDATION}

In conclusion, from the result of this study tick infestation was high and this has serious economic implication as it reduce the productivity of the farmers and also has the potential infliction causes of diseases to both cattle and humans. Therefore, appropriate control measures should be instituted by the authorities to minimize these losses in production as well as educating the farmers on the effect of tick infestation on their cattle and cattle consumers in the study area.

\section{Conflict of interest}

The authors declare no conflict of interest.

Cumming, G. S. (1998): Host preference in African ticks (Acari: Ixodidae): a quantitative data set. B. Entomol. Res. 88: 379-406

Delgado, C., Rosegrant, M., Steinfeld, H., Ehui, S \&Courbois, C. (1999):Livestock to 2020: the next food revolution. IFPRI/FAO/ILRI, Nairobi, Kenya.

Fabiyi, J.P.(2007). Containment of livestock parasites with emphasis on ticks .Nigeria Australia collaborative Agricultural research. Aciar proceeding series No.4: 67-69.

Fabiyi, J.P. (1984): Coping with Clinical Tickborne Disease in Cattle in Nigeria. Nigeria Livestock Farmer 4(3):7-11 
BAJOPAS Volume 12 Number 1, June, 2019

Guglielmone, A. A., Robbins, R.G., Apanaskevich, D.A., Petney, T.N., Estrada-Peña., A., Horak, I.G., et al. (2010): The Argasidae, Ixodidae and Nuttalliellidae (Acari: Ixodida) of the world: a list of valid species names. Zootaxa. 2528:1-28.

Jawara, D.K. (1990). Animal disease as a factor limiting economic development in Africa. Cornell Veterinarian 80:17-25

James-Rugu, N. N. and Iwuala, M. O. E. (1995).The prevalence of ectoparasites of the family Ixodidae on livestock in Jos and environs. Journal of Pest Disease and Vector Management, 1(1):29-32.

James-Rugu, N. N. and Iwuala, M. O. E. (2002).Ectoparasites of some domestic animals in Jos Plateau State, Nigeria. Science forum, 5(1): 149-156

Joseph, E. E., Felicia, N. E., Njoku, I., Chinedu I. A., Ikechukwu E. O., Ngozi, E. E. and Chika, B. I. (2014).Survey of Tick Infestation of Cattle at Four Selected Grazing Sites in the Tropics. Global Veterinaria, 12 (4): 479-486

Malann, Y.D., Deme, G. G., Olanrewaju, C. A. and Abdulkareem, K. A. (2016).A Survey of Tick Infestation on Cattle within Fulani Settlements of the University of Abuja Main Campus, F.C.T., Abuja, Journal Of Biological Science, 2 (5):8189
Obadiah,H. I. and Shekaro, A. (2012). Survey of Tick Infestation in Cattle in Zaria Abattoir, Nigeria Journal of Veterinary Advances, 2(2): 81-87

Obadiah, H. I., Onah, I. E., Ugochukwu, J. U. and Gbinde, A. K. (2017).Tick Infestation of Cattle in Three Markets in Makurdi, North-Central, Nigeria, American Journal of Entomology,1(1):610

Ouhelli, H. and Pandey, V. S. (1982) Prevalence of cattle ticks in Morocco. Tropical Animal Health Production, 14:151-154

Owolabi, Y.H. James, I.J. and Yusuf, K.H. (2015). Relevance of Amblyommavariegatum infestation in the prevalence of bovine dermatophilosis. Proceedings of 40th Annual Conference of Nigerian Society for Animal production. 184pp

Perry, B.D., Randolph, T.F., McDermott, J.J., Sones, K.R. and Thornton, P.K. (2002). Investing in Animal Health Research to Alleviate Poverty. ILRI (International Livestock Research Institute), Nairobi, Kenya.

Wall, R. and Shearer, D. (1997). Veterinary Entomology. 1st edition. Chapman and Hall. London, UK. 265-290pp

Walker, M.D. (2017) Ticks on dogs and cats. The Veterinary Nurse, 8(9):486-492 